\title{
LABOR MARKET EFFECTS OF ECONOMIC INTEGRATION - THE IMPACT OF RE-UNIFICATION IN GERMAN BORDER REGIONS
}

THIESS BUETTNER JOHANNES RINCKE

CESIFO WORKING PAPER NO. 1179

CATEGORY 4: LABOUR MARKETS

APRIL 2004

An electronic version of the paper may be downloaded

- from the CESifo website: www.CESifo.de 


\title{
LABOR MARKET EFFECTS OF ECONOMIC INTEGRATION - THE IMPACT OF RE-UNIFICATION IN GERMAN BORDER REGIONS
}

\begin{abstract}
The paper argues that economic integration causes problems for the labor market of highwage countries due to cross-border labor mobility and the accompanying increase in labor supply. Empirical evidence is provided from an analysis of regional labor market effects of German re-unification. In the aftermath of the re-unification shock, despite some gain in employment, border regions situated on the former German-German border are found to have experienced a fall in the relative wage position and an increase in unemployment relative to other West-German regions. As this points to adverse labor supply effects for resident workers due to cross-border labor mobility, this result is bad news for EU regions situated on the border with the Accession countries in Central and Eastern Europe.
\end{abstract}

JEL classification: J61, R23, F15.

Keywords: economic integration, border regions, EU enlargement, German re-unification, differences in differences estimation.

Thiess Buettner

ZEW

L7, 1

68161 Mannheim

Germany

buettner@zew.de
Johannes Rincke

$Z E W$

L7, 1

68161 Mannheim

Germany

rincke@zew.de

Support by the European Union within the 5th-Framework Program is gratefully acknowledged. The authors also thank Herbert Bruecker for critical discussion of an earlier draft. 


\section{Introduction}

In its recent past Europe has seen the opening up of several internal borders and with the accession of new members states in Central and Eastern Europe to the European Union further borders are bound to fall. This fast unexpected movement has been welcomed by many as a relief from suppression. The probably best known single event is the border removal in the city of Berlin in 1989; the pictures of people from both parts of the border celebrating have been noticed throughout the world. However, in difference to this focal point of history the expected removal of further barriers to mobility at the EU's eastern border is regarded with mixed emotions: the removal of the border is welcomed as it is an impediment to travel and trade, but at the same time the competition with cheap labor from across the border is feared as a threat to the labor market conditions faced by the resident workers. Whereas estimates of the inflow of immigrant workers point to a relatively modest expansion of labor supply (e.g., Boeri and Bruecker, 2001), it is important to note that due to relatively small distances other forms of cross-sectional labor mobility such as weekly or daily commuting is likely to be important. This becomes particulary obvious in the case of Berlin - situated only about 50 miles from the German / Polish border.

Regardless of the actual size of the labor supply expansion in the course of European Enlargement, in order to assess its labor market consequences one might nevertheless consult the literature about the impact of immigration on the labor market of host countries. According to surveys of the literature such as Friedberg and Hunt (1995) or Zimmermann (1995) existing empirical evidence on the impact of immigration on the employment opportunities of native workers shows only quite moderate effects. However, many studies 
rely on cross-sectional differences in immigrant density across local labor markets, where it is quite difficult to identify the labor supply effect of immigration. As recently emphasized in Borjas (2003) if immigrants select themselves into specific labor markets with favorable conditions, empirical results with respect to adverse supply effects on resident workers are likely to be biased and some additional information is needed for identification.

Given this background this paper sheds light on the labor market effects of economic integration, and, in particular, on the impact of cross-border labor mobility. It exploits the significant reduction in impediments to labor mobility in the process of the German reunification in order to identify labor supply shocks in the West German labor market. More specifically, based on the assumption that cost of mobility are increasing in distance, we focus on the impact of the border removal in the regions situated at the German-German border against the reference case of regions in the hinterland. German re-unification is probably one of the most interesting cases of economic integration and its impact on the labor market in recent history, because the impediments to mobility mainly consisted in the border itself. Other impediments to mobility which are often encountered at international borders are largely absent. People at both sides of the border share a common language and the same cultural background. Possibly even more important, due to their formal status as West-German citizens people from East-Germany could immediately enter the West-German labor market even before German re-unification was established at the constitutional level. At the same time re-unification constituted a rather unexpected event, which can be considered as a quasi-experiment for the border regions.

Surprisingly little is known about the consequences of this unique experiment of integra- 
tion in the border regions. Jung (2002) and Kruesemann (2002) provide some descriptive evidence for the eastern border of Lower Saxony pointing towards a deterioration of labor market conditions. However, aside of those case studies, to the best of the authors' knowledge this paper provides the first systematic analysis of the labor market integration shock experienced in the regions at the western side of the former German-German border.

The paper proceeds as follows. The following section provides a theoretical discussion of the possible labor market effects of economic integration, yielding several testable empirical predictions. In particular, it shows that a significant reduction in transaction cost which could possibly arise from a border removal will lead to an employment expansion accompanied with a decline in wages and a rise in unemployment in the high-wage region. Section 3 lays out the investigation approach to test these predictions empirically. Section 4 presents the results, which confirm that in comparison with the labor market development in other parts of West Germany and controlling for other possibly interfering developments, the border regions have in fact seen an increase in employment, a reduction in wages, and an increase in unemployment. The last section provides a conclusion.

\section{Theoretical Considerations}

Basically a border defines the geographic area for which a set of public institutions is defined. As a consequence, by crossing the border an agent may face significant changes in the institutional environment under which he or she operates. As this will often tend to undermine the effectiveness of policies many borders, national borders in particular, constitute significant barriers to mobility. In the present context, we will focus on the 
latter aspect of a border and, thus, the following treats the border simply as an institution which imposes (sometimes prohibitive) transaction cost on the exchange of goods and services between regions or countries.

A removal of a border will significantly expand the opportunities of regions to engage in trade as well as to demand or supply factor services from one region to the other. Hence, the removal of a border can be seen as a discrete change in the degree of integration of goods and factor markets. It is obvious that the reduction of transaction cost may be important for all markets. But in order to focus on local labor market effects consider a simple small open economy which trades goods at internationally fixed prices and lends or supplies capital at a common rate of interest. In this economy, without further assumptions the opening up of the border with another small country which may or may not be open for trade with the rest of the world does not affect the price vector.

To be more precise, let us focus on a country with two regions, a main region (denoted as (1) in Figure 1) and a border region (2). The latter is adjacent to a third region (3), which is part of another country. For simplicity, let regions 2 and 3 be of equal size. In each

Figure 1: Stylized Map of the Regions

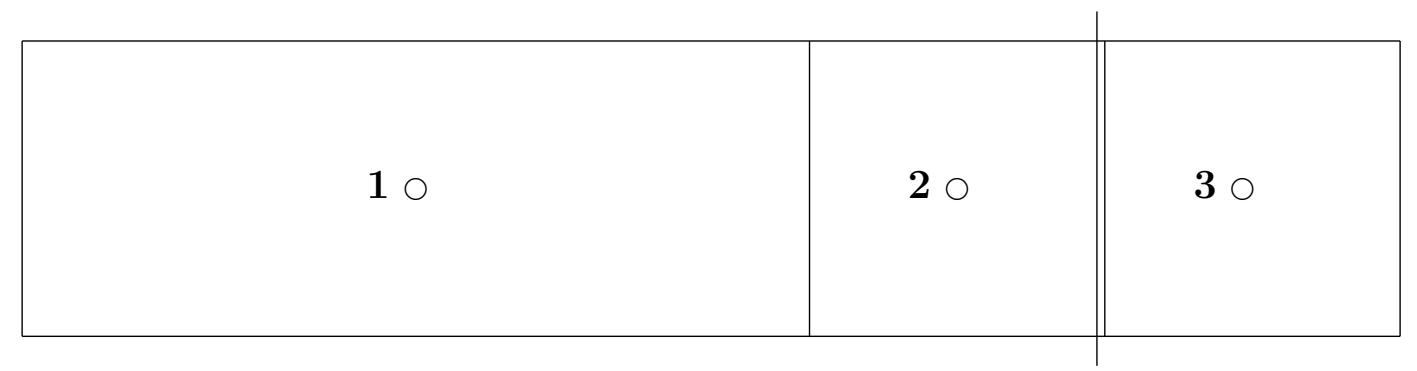

region there is a set of households distributed in space such that the households differ in terms of their cost of mobility. Consider households with place of residence within region 
$i$. Regarding the option to work in region $j$ the spatial distribution of households gives rise to a distribution of the cost of mobility $m_{i j}$. In addition to household-specific cost of mobility further cost result from the imposition of the border between region 2 and 3. Due to the border, mobility between regions 2 and 3 is burdened with additional cost of $\delta$.

For simplicity, assume that cost of mobility are additive. A household faces mobility cost within the region

$$
m_{i, i}=\omega
$$

Let $\omega$ be distributed across households with density $g(\omega)$ in all regions, where $\omega \in[0, \infty]$ and $g(\omega)>0 \forall \omega \in[0, \infty]$. If an individual travels to a neighboring region it faces additional mobility cost $\mu \in[0, \infty]$, such that the total cost of the transfer from region $i$ to region $j$ is

$$
m_{i, j}=\mu+\omega, \quad|i-j|=1 .
$$

Again, let the additional component $\mu$ be distributed identically in all regions. The density of $\mu$ is denoted as $f(\mu)$ with $f(\mu)>0 \forall \mu \in[0, \infty]$. With regard to mobility to more distant regions we assume that for each individual total cost is higher

$$
m_{i, j}>\mu+\omega, \quad|i-j|>1 .
$$

In order to simplify the analysis, we focus in the following on the case where, initially, the wage in region 3 is lower than the wage in regions 1 and 2 , and where wages in regions 1 and 2 are equal. In other words we look at the impact of integration between a low-wage country, represented by region 3, and a high-wage country, consisting of a border region (2) 
and a region in the hinterland (1). With the assumption that $w_{1}=w_{2}>w_{3}$ a household from region 1 will supply labor in region 1 if

$$
\omega<w_{1}
$$

where $w_{1}$ is the market wage in region 1 ; otherwise the household abstains from participating. Supplying labor to region 2 or 3 is not attractive as wages there are not higher. Similarly, a household from region 2 will supply labor to region 2 if

$$
\omega<w_{2}
$$

otherwise the household is not participating. In the initial situation, supplying labor to region 1 or 3 is not attractive as wages there are not higher. Only for households from region 3 the initial situation is such that some may want to supply labor to region 2 . Households from region 3 supply labor to the low-wage region 3 if

$$
\mu \geq w_{2}-\delta-w_{3} \text { and } \omega<w_{3}
$$

but to region 2 if

$$
\mu<w_{2}-\delta-w_{3} \text { and } \omega+\mu<w_{2}-\delta
$$


Consequently, the supply of labor in region 3 is

$$
L_{3}^{S}\left(w_{2}, w_{3}, \delta\right)=\int_{w_{2}-\delta-w_{3}}^{\infty} \int_{0}^{w_{3}} f(\mu) g(\omega) d \omega d \mu=G\left(w_{3}\right)\left[1-F\left(w_{2}-\delta-w_{3}\right)\right]
$$

where $G$ and $F$ are the cdf's of $\omega$ and $\mu$, respectively. For region 2 the supply of labor is determined by

$$
L_{2}^{S}\left(w_{2}, w_{3}, \delta\right)=\int_{0}^{w_{2}} g(\omega) d \omega+\int_{0}^{w_{2}-\delta-w_{3}} \int_{0}^{w_{2}-\delta} h(\lambda, \mu) d \lambda d \mu
$$

where $\lambda=\omega+\mu$ and $h(\mu, \lambda)$ is the joint distribution of mobility cost within and across regions. Noting that $h(\lambda, \mu)=h(\lambda \mid \mu) f(\mu)$, and $h(\lambda \mid \mu)=g(\lambda-\mu)$ we can simplify this expression to

$$
L_{2}^{S}\left(w_{2}, w_{3}, \delta\right)=G\left(w_{2}\right)+\int_{0}^{w_{2}-\delta-w_{3}} \int_{0}^{w_{2}-\delta-\mu} f(\mu) g(\omega) d \omega d \mu
$$

Finally, the supply of labor at 1 is simply

$$
L_{1}^{S}\left(w_{1}\right)=\int_{0}^{w_{1}} g(\omega) d \omega
$$

In order to determine the impact of the transaction $\operatorname{cost} \delta$ on the level of wages we need some assumptions about labor demand. Suppose that employment is chosen such that the marginal product equals the wage rate and suppose that production is determined by a function $F\left(L_{i}, \xi_{i}\right)$, where $L_{i}$ is the labor input and $\xi_{i}$ is a region-specific factor of production. Then, labor market equilibrium is determined by a set of wages $w_{1}, w_{2}, w_{3}$ 
which obey

$$
\begin{aligned}
& L_{1}^{D}\left(w_{1}, \xi_{1}\right)=L_{1}^{S}\left(w_{1}\right) \\
& L_{2}^{D}\left(w_{2}, \xi_{2}\right)=L_{2}^{S}\left(w_{2}, w_{3}, \delta\right) \\
& L_{3}^{D}\left(w_{3}, \xi_{3}\right)=L_{3}^{S}\left(w_{2}, w_{3}, \delta\right),
\end{aligned}
$$

where $L_{i}^{D}$ is the labor demand in region $i$. In this setting we can derive the comparative static effect of a change in the transaction cost on wages and participation in region 2 relative to region 1 . This effect is of particular interest since both regions are assumed to be part of a high-wage country. However, in our setting they differ with respect to their exposure to labor supply shocks resulting from a reduction in the cost of crossing the border between regions 2 and 3 .

To avoid further case distinctions, we assume in the following that the mobility $\operatorname{cost} \delta$ is less than prohibitive. With 'less than prohibitive' we mean $\delta<w_{2}-w_{3}$ such that in all situations considered there is always a strictly positive share of individuals from region 3 supplying labor in region 2.

First, it is helpful to state the partial impact of the transaction cost on labor supply.

Lemma 1 Given wages, a decrease in the transaction cost of mobility $\delta$ will raise labor supply in the border region of the high-wage country.

In order to show that Lemma 1 holds we simply have to differentiate (6). This yields

$$
\frac{\partial L_{2}^{S}}{\partial \delta}=-f\left(w_{2}-\delta-w_{3}\right) G\left(w_{3}\right)-\int_{0}^{w_{2}-\delta-w_{3}} f(\mu) g\left(w_{2}-\delta-\mu\right) d \mu
$$


The statement follows since the expression is strictly negative.

The labor supply increase in the border region following from a decline in mobility cost is at the expense of the low-wage region which is necessarily loosing labor supply. Formally, this can be stated by a Lemma as well.

Lemma 2 Given wages, a decrease in the transaction cost of mobility will lower labor supply in the low-wage region. The decrease of labor supply in the low-wage region is always smaller than the increase of labor supply in the border region of the high-wage country.

Differentiation of (5) yields

$$
\frac{\partial L_{3}^{S}}{\partial \delta}=f\left(w_{2}-\delta-w_{3}\right) G\left(w_{3}\right)
$$

The first statement in Lemma 2 holds since the derivative is strictly positive. The second statement follows since the sum of the partial derivatives from lemmas 1 and 2 is strictly negative:

$$
\frac{\partial L_{2}^{S}}{\partial \delta}+\frac{\partial L_{3}^{S}}{\partial \delta}=-\int_{0}^{w_{2}-\delta-w_{3}} f(\mu) g\left(w_{2}-\delta-\mu\right) d \mu
$$

With regard to the impact of wages in the border region on labor supply, we can state the following:

Lemma $3 A$ decrease of the wage rate in the border region of the high-wage country will lower labor supply in this region and raise labor supply in the low-wage region. The decrease 
of labor supply in the border region of the high-wage country is always larger than the increase of labor supply in the low-wage region.

To show that Lemma 3 holds, we differentiate (6). This gives us

$$
\frac{\partial L_{2}^{S}}{\partial w_{2}}=g\left(w_{2}\right)+f\left(w_{2}-\delta-w_{3}\right) G\left(w_{3}\right)+\int_{0}^{w_{2}-\delta-w_{3}} f(\mu) g\left(w_{2}-\delta-\mu\right) d \mu .
$$

Accordingly, labor supply in region 2 decreases if $w_{2}$ is lowered. Differentiation of (5) yields

$$
\frac{\partial L_{3}^{S}}{\partial w_{2}}=-f\left(w_{2} \delta-w_{3}\right) G\left(w_{3}\right)
$$

which confirms the increase in labor supply in region 3 following from a reduction of the wage rate in region 2 . The sum of the two effects is

$$
\frac{\partial L_{2}^{S}}{\partial w_{2}}+\frac{\partial L_{3}^{S}}{\partial w_{2}}=g\left(w_{2}\right)+\int_{0}^{w_{2}-\delta-w_{3}} f(\mu) g\left(w_{1}-\delta-\mu\right) d \mu
$$

which is strictly positive under our assumptions.

Now we are in a position to derive the impact of the transaction cost of mobility $\delta$ on wages.

Proposition 1 Suppose the slope of the labor demand function is negative. A marginal reduction in the transaction cost of mobility will then reduce the wage rate, raise employment and lower participation in the border region of the high-wage country. 
Proof: Differentiating equations (9) and (10) yields

$$
\begin{aligned}
& \frac{\partial L_{2}^{D}}{\partial w_{2}} d w_{2}=\frac{\partial L_{2}^{S}}{\partial w_{2}} d w_{2}+\frac{\partial L_{2}^{S}}{\partial w_{3}} d w_{3}+\frac{\partial L_{2}^{S}}{\partial \delta} d \delta \\
& \frac{\partial L_{3}^{D}}{\partial w_{3}} d w_{3}=\frac{\partial L_{3}^{S}}{\partial w_{2}} d w_{2}+\frac{\partial L_{3}^{S}}{\partial w_{3}} d w_{3}+\frac{\partial L_{3}^{S}}{\partial \delta} d \delta
\end{aligned}
$$

Solving for $d w_{2} / d \delta$ yields

$$
\begin{aligned}
\frac{d w_{2}}{d \delta}= & \frac{\frac{\partial L_{2}^{S}}{\partial \delta}+\gamma \frac{\partial L_{3}^{S}}{\partial \delta}}{\frac{\partial L_{2}^{D}}{\partial w_{2}}-\frac{\partial L_{2}^{S}}{\partial w_{2}}-\gamma \frac{\partial L_{3}^{S}}{\partial w_{2}}} \\
& \text { where } \\
\gamma \equiv & \frac{\frac{\partial L_{2}^{S}}{\partial w_{3}}}{\frac{\partial L_{3}^{D}}{\partial w_{3}}-\frac{\partial L_{3}^{S}}{\partial w_{3}}}=\frac{f\left(w_{2}-\delta-w_{3}\right) G\left(w_{3}\right)}{-\frac{\partial L_{3}^{D}}{\partial w_{3}}+f\left(w_{2}-\delta-w_{3}\right) G\left(w_{3}\right)+g\left(w_{3}\right)\left[1-F\left(w_{2}-\delta-w_{3}\right)\right]}
\end{aligned}
$$

Note that $0<\gamma<1$. From Lemma 1 and 2 we know that the sum of the two terms in the numerator is negative, even if $\gamma$ were unity. With Lemma 3 also the denominator is negative. This implies that

$$
\frac{d w_{2}}{d \delta}>0
$$

The increase of employment in the high-wage country follows from the negative slope of the labor demand function. The decline in participation in region 2 simply follows from the cdf. of the reservation wage.

Our model thus demonstrates that the reduction or removal of barriers at the border will have a differential effect on regional labor markets in the high-wage country. In our model, under the simplifying assumption of initially equal wages in both regions of the high-wage country, the region which is not adjacent to the low-wage region is not affected by a marginal reduction in the transaction cost of mobility from the low-wage region to 
the high-wage country. The border region, however, is affected due to an increase in labor supply from the low-wage region. Our empirical approach will exploit exactly this difference between border and non-border regions in the high-wage country.

In a more general model, the differential effect of a labor supply shock on border and nonborder regions could be discussed in more detail. If, for instance, there is a positive wage differential between region 1 and region 2 possibly arising from a center-periphery structure, a sort of domino-effect will arise where the integration shock is propagated spatially by the labor supply behavior of residents as is discussed in the case of U.S. immigration (e.g., Filer, 1992, Borjas, Freeman, and Katz, 1997, and Card, 2001). Another interesting extension could refer to the productivity differences $\xi_{1}, \xi_{2}$ and $\xi_{3}$ which have been taken as given, so far. One might argue that with the removal of the border the attraction of labor to the high-wage country will give rise to agglomeration effects and further increases in productivity (Hanson, 1997). However, for the present purpose of studying the integration effect on a border region's labor market, the analysis presented already provides us with a sufficient set of empirical implications.

\section{Investigation Approach}

Empirical evidence on the impact of the removal of barriers at the border on the labor market is obtained from a panel of counties in West Germany. From the total of 327 counties in West Germany (excluding West-Berlin - because of its specific geographic situation) 20 counties are directly situated at the inner-German border. Invoking the above concept of spatial transaction $\operatorname{cost} \delta$ it can be assumed that the decline in spatial transaction cost 
relative to East Germany is particularly effective in these regions. Hence, they should have been exposed more than other regions to the integration shock from re-unification. The empirical analysis exploits the variation in the geographic situation of the counties by means of a "differences in differences" approach, that is we look at the change in the position of labor market indicators in regions at the border relative to other regions. In several respects the labor market integration effects of re-unification in the regions directly situated at the German-German border are a promising subject for this approach. As pointed out by Angrist and Krueger (1999) this approach is " [...] well suited to estimating the effect of sharp changes in the economic environment or government policy." (ibid., p.1296). Certainly, the entire removal of the inner-German border qualifies as such a sharp and drastic change.

Before re-unification, due to the erection of the Berlin Wall in 1961 and the corresponding enforcement of border controls in East Germany, mobility from East to West Germany was severely suppressed. ${ }^{1}$ But, when the Berlin Wall tumbled in November 1989 people from East Germany were free to leave their country. ${ }^{2}$ In the subsequent months, re-unification was put forward in a quick succession of events. Commuting cost across the border were quickly lowered by improving, or reviving, roads, public transport and communication systems. The political decision process accompanying re-unification had its most remarkable points in the treaty concerned with the creation of the monetary and economic union be-

\footnotetext{
${ }^{1}$ Whereas in the 12 years between 1949 and 1961 approximately 2.7 Million people moved to the west, in the period between 1962 and 1989 only 0.6 Million people came (Sinn and Sinn, 1992).

${ }^{2}$ Already in 1989 a total of about 0.39 Million individuals moved to West Germany, followed by nearly 0.4 Million in 1990 (Statistisches Bundesamt, 1999). The mass exodus had begun already before November 9 across the Hungarian-Austrian border and via the West German embassies in Prague and Budapest, but the majority of people who left the GDR in 1989 came across the German-German border after the lifting of the "Iron Curtain".
} 
tween both German States, which came into force on July 1, 1990, and the treaty concerned with the political re-unification, three months later on October 3.

Already before 1990 citizens from East-Germany were formally treated as German citizens in West Germany. Thus, with the barriers to entry falling in November 1989 East German citizens could immediately enter the West-German labor market at drastically reduced transaction cost. As the West German labor market was and still is characterized by significantly higher wages, and since unemployment quickly rose in East Germans due to the collapse of socialist economy, it seems reasonable to expect an expansion of labor supply in the West-German labor market after re-unification, in particular, in the border regions. A further, important characteristic of German re-unification is the high degree of unexpectedness. Although it seems hard to understand nowadays, still in 1989 the vast majority of Germans - at least in the West - did not take the opening up of the GermanGerman border as a serious possibility. All this justifies to consider the removal of barriers at the German - German border as a sharp change in the economic environment of the border regions and, therefore, a differences in differences approach seems appropriate in order to test for its labor market effects.

Basically, the analysis summarizes the development of key labor market indicators before and after the re-unification shock by regressions of the following type

$$
\begin{aligned}
y_{i, t} & =\beta_{2}\left(d_{2, t} \times \text { Border }_{i}\right)+\cdots+\beta_{T}\left(d_{T, t} \times \text { Border }_{i}\right) \\
& +\theta_{2} d_{2, t}+\cdots+\theta_{T} d_{T, t}+\pi_{i, t}+\alpha_{i}+u_{i, t}
\end{aligned}
$$

To capture common trends for each dependent variable $y_{i, t}$ we include a set of time dummies 
$d_{2, t}, \ldots, d_{T, t}$ such that $d_{s, t}=1$ if $s=t$, and zero otherwise. Time-invariant characteristics of regions are captured by the fixed regional effect $\alpha_{i}$. In difference to the well known study of Card (1990) on the "Mariel boatlift" the exposition to the shock is not captured by a single variable, but by a couple of interaction terms between the geographic situation of a county at the border and the respective year. This reflects the fact that the economic integration between the two parts of Germany constituted not just a single shock in 1990, after the border fell, but rather a sequence of shocks. The setting deviates further from the study of Card (1990) in introducing an explicit control variable, which reflects the availability of investment subsidies due to German regional policy. More specifically, we introduce a dummy variable $\pi_{i, t}$ which is unity if a county encloses locations eligible for investment subsidies. Note that this variable is time-varying at the local level as the regional policy is revised annually and has been reorganized substantially in the aftermath of re-unification. ${ }^{3}$

In order to test for the effects of integration as outlined in Section 2 the empirical analysis uses a variety of different indicator variables for the development of local labor markets, including not only wages, salaries, and employment, but also the local unemployment rate. The latter variable is important because no other indicator of the participation of the resident population is available; employment figures refer to the location of the employer

\footnotetext{
${ }^{3}$ In West Germany, regional policy before 1989 was focussed on two types of regions. Firstly, a program called 'Improvement of regional economic structure' for regions with poor economic performance or suffering from structural change is in place since 1969. The main tool of this program is investment subsidies. Secondly, regional policy has been concerned with regions at the German-German border, the so-called 'Zonenrandgebiet'. They were considered to be severely disadvantaged by their location and given access to all measures of the 'Improvement (...)' program. After re-unification, the focus of German regional policy shifted to East Germany. The concept of 'Zonenrandgebiet' was effectively dropped in September 1991, and already since October 3, 1990 all regions in East Germany had access to the 'Improvement (...)' program. However, also after 1990 there have always been several regions in West Germany, both in the former 'Zonenrandgebiet' and outside, that had access to measures of German regional policy.
} 
and not to the place of residence of the household. Thus, they are not indicative of the participation of the resident population.

Table 1: Descriptive Statistics

\begin{tabular}{|c|c|c|c|c|c|}
\hline & Nobs & Mean & Std Dev & Min & $\operatorname{Max}$ \\
\hline Unemployment rate (in \%) & 4562 & 8.25 & 3.11 & 2.27 & 20.9 \\
\hline Employment per capita & 4890 & .331 & .116 & .126 & .942 \\
\hline Population (in 1000) & 4890 & 192 & 163 & 33.0 & 1710 \\
\hline Hours per empl. (Manuf.) & 3272 & 1.15 & .840 & .321 & 12.1 \\
\hline Investment per empl. (Manuf.) ${ }^{a}$ & 3273 & 11.9 & 5.07 & 2.89 & 65.7 \\
\hline Wage (per day) ${ }^{a}$ & 3912 & 124 & 27.8 & 70.5 & 198 \\
\hline Salary (per day) ${ }^{a}$ & 3911 & 158 & 35.8 & 81.6 & 246 \\
\hline Regional policy & 4890 & .445 & .494 & .00 & 1.00 \\
\hline
\end{tabular}

${ }^{a}$ measured in Deutsche Mark and 2000-Prices. Sample size varies due to missing values.

\section{Results}

The first column in Table 2 reports results for the rate of unemployment as the dependent variable. Starting in 1990, border regions show a significant increase in unemployment relative to 1987 and the differential grows to $2.28 \%$ in 2000 . Thus, the results indicate that the opening of the border resulted in a strong, persistent and significant disadvantage of border regions relative to the base year 1987 in terms of unemployment. The dummy for regional policy is positive and significant, indicating that unemployment is higher in regions subject to special investment incentives provided by regional policy. However, note that the coefficient reflects both the distribution of investment subsidies as well as their impact on the economy. Thus, it is not clear whether the positive significance indicates a failure of regional policy to reduce unemployment or just the selection of regions into the program. 
Columns (2) to (4) in Table 3 depict results for total employment and population. The employment series shows a positive development after re-unification. For the period between 1991 and 1997 the employment differential relative to the base year is significantly positive. However, at the end of the time period analyzed a decline in employment - albeit not significant - is found. Despite of the, at least, temporary increase in employment, population shows a growing negative differential in the border regions. In 2000 the population is reduced by almost $3 \%$ relative to the period 1986. Taking together, employment per capita is significantly increased in the periods after re-unification.

In order to see whether further employment effects in terms of hours have occurred after reunification, column (5) reports some statistics for the hours worked (for blue-collar workers only) in the manufacturing industry scaled with the number of employees (including whitecollars). However, no significant increase in hours is found. The scaling of hours worked by the total number of employees is certainly a problem, but the number of blue-collar workers was not available.

In order to interpret the border development as indicative of the integration effect on the labor market it is important to control for the presence of investment subsidies due to regional policy, in particular, because of the cutback of those subsidies in the aftermath of re-unification. Therefore, all regressions employ the dummy for presence of those subsidies already mentioned before. To test whether this dummy is in fact able to control for the cutback of investment subsidies an alternative regression has been carried out for investment per employee in manufacturing. If regional policy is sufficiently captured by this dummy variable the investment series scaled with employment and conditional on the regional policy dummy should not display a significant difference in the development of the 
Table 2: Estimation Results

\begin{tabular}{|c|c|c|c|c|c|c|}
\hline Dep. Variable & $\begin{array}{c}\text { Unemp. } \\
\text { (1) }\end{array}$ & $\begin{array}{c}\log \text { Emp. } \\
(2)\end{array}$ & $\begin{array}{c}\log \text { Pop. } \\
(3)\end{array}$ & $\log \frac{\text { Emp. }}{\text { Pop. }}$ & $\log \frac{\text { Hrs. }}{\text { Emp. }}$ & $\log \frac{\text { Inv. }}{\text { Emp. }}$ \\
\hline Border $\times($ year $=87)$ & & $\begin{array}{l}.002 \\
(.015)\end{array}$ & $\begin{array}{l}-.008 \\
(.013)\end{array}$ & $\begin{array}{l}.006 \\
(.010)\end{array}$ & & \\
\hline Border $\times($ year $=88)$ & $\begin{array}{l}.247 \\
(.441)\end{array}$ & $\begin{array}{l}-.008 \\
(.014)\end{array}$ & $\begin{array}{l}-.014 \\
(.012)\end{array}$ & $\begin{array}{l}.006 \\
(.010)\end{array}$ & & \\
\hline Border $\times($ year $=89)$ & $\begin{array}{c}.598 \\
(.394)\end{array}$ & $\begin{array}{l}-.011 \\
(.013)\end{array}$ & $\begin{array}{l}-.017 \\
(.011)\end{array}$ & $\begin{array}{c}.007 \\
(.010)\end{array}$ & & \\
\hline Border $\times($ year $=90)$ & $\begin{array}{l}1.16^{\star \star} \\
(.370)\end{array}$ & $\begin{array}{l}-.000 \\
(.013)\end{array}$ & $\begin{array}{l}-.015 \\
(.011)\end{array}$ & $\begin{array}{c}.014 \\
(.010)\end{array}$ & $\begin{array}{l}.009 \\
(.030)\end{array}$ & $\begin{array}{l}-.067 \\
(.102)\end{array}$ \\
\hline Border $\times($ year $=91)$ & $\begin{array}{l}1.34 \\
(.362)\end{array}$ & $\begin{array}{l}.028^{\star \star} \\
(.013)\end{array}$ & $\begin{array}{l}-.019 \text { * } \\
(.011)\end{array}$ & $\begin{array}{l}.047^{\star \star} \\
(.010)\end{array}$ & $\begin{array}{l}.190 \\
(.201)\end{array}$ & $\begin{array}{l}-.032 \\
(.110)\end{array}$ \\
\hline Border $\times($ year $=92)$ & $\begin{array}{l}1.19 \\
(.363)\end{array}$ & $\begin{array}{l}.027^{\star \star} \\
(.013)\end{array}$ & $\begin{array}{l}-.022^{\star \star} \\
(.010)\end{array}$ & $\begin{array}{l}.049 \\
(.010)\end{array}$ & $\begin{array}{c}.009 \\
(.039)\end{array}$ & $\begin{array}{c}.037 \\
(.112)\end{array}$ \\
\hline Border $\times($ year $=93)$ & $\begin{array}{l}1.22^{\star \star} \\
(.376)\end{array}$ & $\begin{array}{l}.028^{\star \star} \\
(.012)\end{array}$ & $\begin{array}{l}-.022^{\star \star} \\
(.010)\end{array}$ & $\begin{array}{l}.050^{\star \star} \\
(.010)\end{array}$ & $\begin{array}{c}.023 \\
(.030)\end{array}$ & $\begin{array}{l}-.083 \\
(.104)\end{array}$ \\
\hline Border $\times($ year $=94)$ & $\begin{array}{l}1.18^{\star \star} \\
(.409)\end{array}$ & $\begin{array}{l}.035^{\star \star} \\
(.012)\end{array}$ & $\begin{array}{l}-.021 \\
(.010)\end{array}$ & $\begin{array}{l}.056^{\star \star} \\
(.010)\end{array}$ & $\begin{array}{c}.023 \\
(.030)\end{array}$ & $\begin{array}{l}-.019 \\
(.106)\end{array}$ \\
\hline Border $\times($ year $=95)$ & $\begin{array}{l}1.36 \\
(.419)\end{array}$ & $\begin{array}{l}.040^{\star \star} \\
(.012)\end{array}$ & $\begin{array}{l}-.021 \\
(.010)\end{array}$ & $\begin{array}{l}.060 \\
(.010)\end{array}$ & $\begin{array}{c}.024 \\
(.029)\end{array}$ & $\begin{array}{l}-.060 \\
(.097)\end{array}$ \\
\hline Border $\times($ year $=96)$ & $\begin{array}{l}1.70^{\star \star} \\
(.419)\end{array}$ & $\begin{array}{l}.031 \\
(.013)\end{array}$ & $\begin{array}{l}-.022^{\star \star} \\
(.011)\end{array}$ & $\begin{array}{l}.053^{\star \star} \\
(.010)\end{array}$ & $\begin{array}{c}.039 \\
(.031)\end{array}$ & $\begin{array}{l}-.072 \\
(.109)\end{array}$ \\
\hline Border $\times($ year $=97)$ & $\begin{array}{l}1.90 \\
(.384)\end{array}$ & $\begin{array}{l}.030^{\star \star} \\
(.014)\end{array}$ & $\begin{array}{l}-.020 \text { } \\
(.012)\end{array}$ & $\begin{array}{l}.050^{\star \star} \\
(.010)\end{array}$ & $\begin{array}{c}.039 \\
(.031)\end{array}$ & $\begin{array}{l}-.043 \\
(.113)\end{array}$ \\
\hline Border $\times($ year $=98)$ & $\begin{array}{l}1.98 \\
(.371)\end{array}$ & $\begin{array}{l}.021 \\
(.015)\end{array}$ & 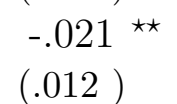 & $\begin{array}{l}.042^{\star \star} \\
(.010)\end{array}$ & $\begin{array}{c}.023 \\
(.029)\end{array}$ & $\begin{array}{l}-.162 \\
(.115)\end{array}$ \\
\hline Border $\times($ year $=99)$ & $\begin{array}{l}2.08 \\
(.387)\end{array}$ & $\begin{array}{c}.010 \\
(.017)\end{array}$ & $\begin{array}{l}-.023 \\
(.013)\end{array}$ & $\begin{array}{l}.032^{\star \star} \\
(.011)\end{array}$ & $\begin{array}{c}.036 \\
(.031)\end{array}$ & $\begin{array}{l}-.110 \\
(.132)\end{array}$ \\
\hline Border $\times($ year $=00)$ & $\begin{array}{l}2.28 \\
(.385)\end{array}$ & $\begin{array}{l}-.010 \\
(.017)\end{array}$ & $\begin{array}{l}-.029 \\
(.014)\end{array}$ & $\begin{array}{c}.018 \\
(.011)\end{array}$ & & \\
\hline Regional policy & $\begin{array}{l}.124 \\
(.049)\end{array}$ & $\begin{array}{l}-.037^{\star \star} \\
(.002)\end{array}$ & $\begin{array}{l}-.015^{\star \star} \\
(.001)\end{array}$ & $\begin{array}{l}-.022^{\star \star} \\
(.002)\end{array}$ & $\begin{array}{c}.012 \\
(.014)\end{array}$ & $\begin{array}{l}.0811^{\star \star} \\
(.020)\end{array}$ \\
\hline Time period & $87-00$ & $86-00$ & $86-00$ & $86-00$ & $89-99$ & 89-99 \\
\hline$R^{2}$ & .937 & .996 & .999 & .988 & .442 & .602 \\
\hline Nobs. & 4,562 & 4,890 & 4,890 & 4,890 & 3,272 & 3,273 \\
\hline
\end{tabular}

Heteroskedasticity consistent standard errors in parentheses. A star denotes significance at the $10 \%$-level, two stars denote significance at 5\%-level. All estimations include a full set of regional and time fixed effects. 
border regions. Column (6) reports corresponding results. On the one hand, investments in manufacturing in border regions show no systematically different reaction to the integration shock than investments in non-border regions. On the other hand, the provision of investment incentives proves highly significant suggesting that, in fact, regional policy has been effective in creating investment. Thus, the results confirm that the dummy variable for regional policy is a sufficient indicator of investment incentives in our specification.

The results for wages and salaries of low and medium skilled employees are presented in Table 3. Columns (7) and (8) report results for simple regressions following the "differences in differences" methodology. From 1991 on, wages are significantly lower in border regions compared to non-border regions. Once more, the effects are persistent and highly significant. From 1991 to 1997, the average wage in border regions is between $2.1 \%$ and $4.2 \%$ lower than in the base period. Also for salaries a negative development is found, although the interaction terms between the border and period effects are not significant.

Columns (9) and (10) report further results on wages and salaries obtained from regressions using individual data. These regressions include some additional controls for the characteristics of the workers in terms of age and education as in a standard Mincer-type wage regression. In addition, these regressions exploit the information about the industry affiliation of each worker and introduce controls for the industry as well as indicators for hours worked in the considered industry and negotiated wages according to the corresponding industry level wage agreement. ${ }^{4}$ The negative development in the wage level is still confirmed, even though the individual characteristics as well as the industry charac-

\footnotetext{
${ }^{4}$ This variable is taken from Buettner and Fitzenberger, 2002.
} 
Table 3: Estimation Results, continued

\begin{tabular}{|c|c|c|c|c|c|c|}
\hline Dep. Variable & $\begin{array}{c}\text { log Wage } \\
(7)\end{array}$ & $\begin{array}{c}\log \text { Salar. } \\
(8)\end{array}$ & $\begin{array}{c}\log \mathrm{Wag} \\
(9)\end{array}$ & & \multicolumn{2}{|c|}{$\begin{array}{c}\log \text { Salar. } \\
(10)\end{array}$} \\
\hline $\log$ Hours & & & $\begin{array}{c}.551 \\
(.055)\end{array}$ & $\star \star \star$ & & \\
\hline log Contract wage & & & $\begin{array}{l}.377 \\
(.043)\end{array}$ & $\star \star$ & $\begin{array}{l}.029 \\
(.052)\end{array}$ & \\
\hline Skill & & & $\begin{array}{l}.088 \\
(.001)\end{array}$ & $\star \star$ & $\begin{array}{l}.090 \\
(.004)\end{array}$ & $\star \star$ \\
\hline Age & & & $\begin{array}{c}.333 \\
(.003)\end{array}$ & $\star \star$ & $\begin{array}{c}.698 \\
(.006)\end{array}$ & $\star \star$ \\
\hline Age, squared & & & $\begin{array}{l}-.037 \\
(.000)\end{array}$ & $\star \star$ & $\begin{array}{l}-.073 \\
(.001)\end{array}$ & $\star \star$ \\
\hline Border $\times($ year $=87)$ & $\begin{array}{l}-.005 \\
(.008)\end{array}$ & $\begin{array}{l}-.002 \\
(.015)\end{array}$ & $\begin{array}{l}-.005 \\
(.007)\end{array}$ & & $\begin{array}{l}-.001 \\
(.009)\end{array}$ & \\
\hline Border $\times($ year $=88)$ & $\begin{array}{l}-.010 \\
(.008)\end{array}$ & $\begin{array}{l}-.010 \\
(.012)\end{array}$ & $\begin{array}{l}-.007 \\
(.008)\end{array}$ & & $\begin{array}{l}-.015 \\
(.010)\end{array}$ & \\
\hline Border $\times($ year $=89)$ & $\begin{array}{l}-.012 \\
(.008)\end{array}$ & $\begin{array}{l}-.000 \\
(.010)\end{array}$ & $\begin{array}{l}-.008 \\
(.007)\end{array}$ & & $\begin{array}{l}-.016 \\
(.007)\end{array}$ & $\star \star$ \\
\hline Border $\times($ year $=90)$ & $\begin{array}{l}-.010 \\
(.008)\end{array}$ & $\begin{array}{c}.013 \\
(.012)\end{array}$ & $\begin{array}{l}-.010 \\
(.007)\end{array}$ & & $\begin{array}{c}.001 \\
(.009)\end{array}$ & \\
\hline Border $\times($ year $=91)$ & 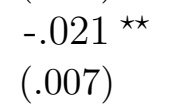 & $\begin{array}{c}.004 \\
(.010)\end{array}$ & $\begin{array}{l}-.015 \\
(.006)\end{array}$ & * & $\begin{array}{c}.004 \\
(.008)\end{array}$ & \\
\hline Border $\times($ year $=92)$ & $\begin{array}{l}-.025^{\star \star} \\
(.007)\end{array}$ & $\begin{array}{l}-.003 \\
(.015)\end{array}$ & $\begin{array}{l}-.013 \\
(.006)\end{array}$ & $\star$ & $\begin{array}{l}-.004 \\
(.011)\end{array}$ & \\
\hline Border $\times($ year $=93)$ & $\begin{array}{l}-.0266^{\star \star} \\
(.007)\end{array}$ & $\begin{array}{l}-.008 \\
(.012)\end{array}$ & $\begin{array}{r}-.022 \\
(.006)\end{array}$ & $\star \star$ & $\begin{array}{l}-.019 \\
(.008)\end{array}$ & $\star \star$ \\
\hline Border $\times($ year $=94)$ & $\begin{array}{l}-.022^{\star \star} \\
(.008)\end{array}$ & $\begin{array}{l}-.007 \\
(.011)\end{array}$ & $\begin{array}{l}-.018 \\
(.007)\end{array}$ & $\star \star$ & $\begin{array}{l}-.023 \\
(.008)\end{array}$ & $\star \star$ \\
\hline Border $\times($ year $=95)$ & 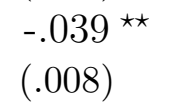 & $\begin{array}{c}.000 \\
(.013)\end{array}$ & $\begin{array}{l}-.026 \\
(.007)\end{array}$ & $\star \star$ & $\begin{array}{l}-.018 \\
(.012)\end{array}$ & \\
\hline Border $\times($ year $=96)$ & $\begin{array}{l}-.042^{\star \star} \\
(.008)\end{array}$ & $\begin{array}{l}-.015 \\
(.011)\end{array}$ & $\begin{array}{l}-.028 \\
(.007)\end{array}$ & $\star \star$ & $\begin{array}{l}-.024 \\
(.010)\end{array}$ & $\star \star$ \\
\hline Border $\times($ year $=97)$ & $\begin{array}{l}-.032^{\star \star} \\
(.008)\end{array}$ & $\begin{array}{c}.002 \\
(.014)\end{array}$ & $\begin{array}{l}-.027 \\
(.007)\end{array}$ & $\star \star$ & $\begin{array}{l}-.021 \\
(.019)\end{array}$ & $\star \star$ \\
\hline Regional policy & $\begin{array}{l}-.006^{\star \star} \\
(.001)\end{array}$ & $\begin{array}{l}.005 \text { * } \\
(.003)\end{array}$ & $\begin{array}{l}-.004 \\
(.001)\end{array}$ & $\star \star$ & $\begin{array}{l}.003 \\
(.002)\end{array}$ & * \\
\hline Time period & $86-97$ & $86-97$ & $86-97$ & & $86-97$ & \\
\hline$R^{2}$ & .978 & .935 & $.366^{a}$ & & $.416^{a}$ & \\
\hline Nobs. & 3,912 & 3,911 & 555,578 & & 280,254 & \\
\hline
\end{tabular}

If indexed with ${ }^{a} R^{2}$ refers to the data after within transformation. Columns (7) and (8) report heteroskedasticity consistent standard errors in parentheses. Columns (9) and (10) report standard errors obtained from a Huber / White Sandwich estimator taking account of the dependence within regions. A star denotes significance at the $10 \%$-level, two stars denote significance at $5 \%$-level. All estimations include a full set of regional and time fixed effects. Columns (9) and (10) also include industry dummies. 
teristics are highly significant, pointing to the typical age and education effects and to a significant impact of industry characteristics. This shows that the simple "differences in differences" approach is not yielding spurious results: differences in the composition of the workforce cannot explain the observed trend towards lower wages in the border region in the aftermath of re-unification.

Following conventional practice the results have been obtained relying on robust inference with regard to heteroscedasticity and random group effects (e.g., Moulton, 1990) in case of individual data. Recently, Bertrand, Duflo, and Mullainthan (2004) have criticized this practice for its neglect of possible autocorrelation. They show that the conventional approach in presence of autocorrelation tends to overreject the null-hypotheses of no-treatment effect. As a particularly simple but effective remedy against false rejections of the null-hypothesis they suggest to first run a basic regression without the treatment effect, and then to test for the treatment effect using aggregates of the residuals before and after the shock. ${ }^{5}$

Aside of its simplicity this approach is appealing due to its transparency and reliance on

${ }^{5}$ Formally, the approach starts with estimating

$$
y_{i, t}=\theta_{2} d_{2, t}+\cdots+\theta_{T} d_{T, t}+\pi_{i, t}+\alpha_{i}+u_{i, t} .
$$

The estimated residuals are then aggregated into two periods, one before $\left(\widehat{v}_{i, 1}\right)$ and the other after $\left(\widehat{v}_{i, 2}\right)$ the re-unification shock starting in period $s$,

$$
\widehat{v}_{i, 1} \equiv \frac{1}{p} \sum_{t=1}^{p} \widehat{u}_{i, s-t} \quad \widehat{v}_{i, 2} \equiv \frac{1}{1+q} \sum_{t=0}^{q} \widehat{u}_{i, s+t} .
$$

Finally, the aggregated residuals are regressed on the border effect and time- as well as region-specific fixed effects in the two-period panel regression

$$
\hat{v}_{i, t}=\beta\left(d_{2, t} \times \text { Border }_{i}\right)+\theta d_{2, t}+\alpha_{i}+\epsilon_{i, t} \quad t=1,2,
$$

where period 1 is before and period 2 is after re-unification such that $\beta$ captures the treatment effect. 
Table 4: Estimation Results based on Residual Aggregation

\begin{tabular}{lcccccc}
\hline \hline \multirow{2}{*}{ Dep. Variable } & Unemp. & log Emp. & $\log$ Pop. & $\log \frac{\text { Emp. }}{\text { Pop. }}$ & $\log \frac{\text { Hrs. }}{\text { Emp. }}$ & $\log \frac{\text { Inv. }}{\text { Emp. }}$ \\
& $(1)$ & $(2)$ & $(3)$ & $(4)$ & $(5)$ & $(6)$ \\
\hline Border $\times($ year=90) & $.937 \star \star$ & $.029^{\star \star}$ & $-.010^{\star}$ & $.038^{\star \star}$ & .046 & .033 \\
& $(.292)$ & $(.007)$ & $(.053)$ & $(.006)$ & $(.045)$ & $(.046)$ \\
\hline$R^{2}$ & .446 & .652 & .680 & .552 & .150 & .598 \\
Nobs. & 652 & 652 & 652 & 652 & 455 & 448 \\
\hline
\end{tabular}

Dep. Variable $\quad \log$ Wage log Salar. log Wage log Salar.

\begin{tabular}{lcccc} 
& $(7)$ & $(8)$ & $(9)$ & $(10)$ \\
\hline Border $\times($ year $=90)$ & $-.017^{\star \star}$ & .003 & $-.011^{\star \star}$ & .008 \\
& $(.005)$ & $(.010)$ & $(.005)$ & $(.010)$ \\
\hline$R^{2}$ & .240 & .242 & .955 & .895 \\
Nobs. & 652 & 651 & 652 & 652 \\
\hline
\end{tabular}

Results of estimations following the suggestions of Bertrand, Duflo, and Mullainthan (2004), see text for further explanation. Heteroskedasticity consistent standard errors in parentheses. A star denotes significance at the $10 \%$-level, two stars denote significance at 5\%-level. All estimations include a constant, a time-specific fixed effect and a full set of regional fixed effects.

standard procedures. Table 4 displays corresponding results for each of the series analyzed above. In order to restrict attention to the re-unification effect the estimates focus on the period in the first five years after re-unification (1990-1994) relative to the periods before re-unification using up to four periods (1986-1989). ${ }^{6}$ Nevertheless, all of the previous results are clearly confirmed. In the period after re-unification, unemployment and employment are significantly higher, and wages are significantly lower in the border regions. Note that as in the above results salaries do not show a significant effect. ${ }^{7}$

\footnotetext{
${ }^{6}$ Sensitivity analysis reveals that extending or reducing the post-unification period considered has little effects on the results.

${ }^{7}$ Note the high $\mathrm{R}^{2}$ in specifications (9) and (10), which reflects the control for individual characteristics in the underlying regressions using individual data.
} 
Taking together the results are clearly in accordance with the predictions of our theoretical model. If in fact the removal of the border barriers has contributed to a higher labor supply in the regions situated in West-Germany close to the German-German border, total employment should have increased. At the same time wages should be reduced, relatively, and, furthermore, the participation of the residents in these regions should fall, possibly causing an increase in the local unemployment rate. The empirical analysis has shown that all of these predicted trends are supported in the data. The adverse population trend is in accordance with the decline in the relative attractiveness of the labor market of border regions and highlights, once again, the importance of cross-border mobility other than migration.

\section{Conclusion}

From the analysis presented in this paper we can conclude that labor market competition from across the border is a plausible explanation for the joint movement of labor market conditions in West German border regions in the aftermath of German re-unification. More specifically, the results suggest that in line with the predictions from the theoretical analysis

workers from East Germany commuting but not necessarily migrating to West German border regions expanded labor supply and led to lower wages and higher unemployment among resident workers even though employment in these regions has been increased.

The results cast doubts about the prospects for the labor markets in EU regions situated at the EU border with the Accession countries in Central and Eastern Europe in the course of EU Enlargement. One has to be careful, however, in translating the findings of 
the present paper to the case of EU Enlargement. One important difference between EU Enlargement and the integration at the German-German border is that the accession of the Central and Eastern European Countries is an expected event individuals and firms have begun to anticipate years before integration itself is now going to take place. Workers from these countries already today commute across the border into the EU, and goods markets are already today at least partly integrated. Therefore, we would expect to find less pronounced integration effects for the EU border regions to Central and Eastern Europe after the accession of these countries to the EU. However, even though it is difficult to say to which extent the integration effect in the labor market has already taken place, the results presented suggest that there is a cost of EU-Enlargement to the EU countries as, ceteris paribus, resident workers suffer from a deterioration of labor market conditions due to cross-border labor mobility.

\section{Data Sources and Definitions}

The dataset consists of all 327 counties and independent cities (Kreise und kreisfreie Städte) in West-Germany. The city of Wolfsburg is excluded due to some data restrictions.

Annual population is the average of quarterly figures, official projections based on census data and resident registration information.

Unemployment rate is the official annual figure for the city or county as reported in the statistics provided by the Federal Employment Service.

Total employment refers to the number of employed at the end of June at each year at 
local establishments as reported in the employment statistics based on the complete set of social security accounts.

Manufacturing employment refers to employment in manufacturing establishments (Produzierendes Gewerbe) as reported by the Statistical Offices of the German States.

Wages and Salaries: The wage rate refers to the gross daily wage for a male full-time (blue-collar) worker with low or medium skill level as taken from the IABS-REG scientific use file of a $1 \%$ random sample of the social security accounts. As the data are top-coded at the upper social security threshold, we restrict attention to low and medium skilled workers. Specifications (7) and (8) employ means of the daily remuneration as of June 30th in the considered region and period. Specification (9) and (10) use the underlying individual data.

Age and skill: The age is the individual age as reported in the IABS-REG. Skill is a dummy reflecting the existence of a vocational training degree. Note that highly skilled employees, i.e. with a technical college ("Fachhochschule") or university degree, are removed entirely from the dataset in order to avoid problems from the top-coding of the remuneration figures.

Industry dummies for 40 manufacturing and non-manufacturing sectors according to the industry classification used by the Federal Labor Office.

Hours: Average weekly hours paid at the industry level for 40 manufacturing and nonmanufacturing sectors (for male blue collar workers only). Source: German Statistical Office ("Statistisches Bundesamt", FS 16,2, Segmente 1612-1615, 5565-5568). 
Contract wages of blue collar workers: Industry specific index of hourly contract wages of male blue collar workers $(1991=100)$. Source: German Statistical Office ("Statistisches Bundesamt", FS 16,4.3, Segment 2561).

Contract wages of white collar workers: Industry specific index of monthly contract wages of male white collar workers $(1991=100)$. Source: German Statistical Office ("Statistisches Bundesamt", FS 16,4.3, Segment 2554).

Regional policy is a dummy variable for counties enclosing locations eligible for investment subsidies. For all years up to 1991, it is set to unity if for county $i$ in year $t$ at least one of the following two conditions was satisfied:

1. The county encloses locations eligible for investment subsidies from the 'Improvement of regional economic structure'-programm.

2. The county encloses locations which belong to the so-called 'Zonenrandgebiet'.

For all years after 1991, the second condition is dropped since from the year 1992 onwards belonging to the former 'Zonenrandgebiet' does no longer affect on the eligibility for investment subsidies. If all locations in county $i$ lose their status of being eligible for subsidies during year $t, \pi_{i t}$ was set to $m / 12$, where $m$ is the number of months in year $t$ in which firms could still apply for subsidies. All information concerning eligibility was taken from the annual report 'Rahmenplan der Gemeinschaftsaufgabe Verbesserung der regionalen Wirtschaftsstruktur'. 


\section{References}

Angrist, J. D. and A. B. Krueger. 1999. Empirical strategies in labor economics. In: Ashenfelter, O. (ed.). Handbook of Labor Economics, Vol.3A, Amsterdam et al., $1277-1366$.

Bertrand, M., Duflo, E. and S. Mullainathan. 2004. How much should we trust differences in differences estimates. Quarterly Journal of Economics 119, 249-275.

Boeri, T. and H. Bruecker. 2001. Eastern Enlargement and EU labour markets : perceptions, challenges and opportunities. World economics 2, 49-68.

Borjas, G. J. 2003. The labor demand curve is downward sloping: reexamining the impact of immigration on the labor market. Quarterly Journal of Economics 118, 1335-1374.

Borjas, G. J., Freeman, R. B. and L. F. Katz. 1997. How much do immigration and trade affect labor market outcomes? Brookings Papers on Economic Activity 1 (1997), $1-67$.

Buettner, T. and B. Fitzenberger. 2002. Integrating wage bargaining into an efficiency wage model: the relationship between wages and unemployment revisited, unpublished manuscript, Mannheim.

Card, D. E. 1990. The impact of the Mariel Boatlift on the Miami labor market. Industrial \& Labor Relations Review 43 (1990), 2, 245-257.

Card, D. E. 2001. Immigrant inflows, native outflows, and the local labor market impact of higher immigration. Journal of Labor Economics 19 (2001), 1, 22-64.

Filer, R. K. 1992. The impact of immigrant arrivals on migratory patterns of native workers. In: Borjas, G. J. and R. B. Freeman. Immigration and the Work Force: Economic Consequences for the United States and Source Areas, Chicago, 245-269. 
Friedberg, R. M. and J. Hunt. 1995. The impact of immigrants on host country wages, employment and growth. Journal of Economic Perspectives 9 (1995), 23-44.

Hanson, G. H. 1997. Increasing returns, trade and the regional structure of wages. Economic Journal 107 (1997), January, 113-133.

Jung, H.-U. 2001. Entwicklungsprobleme und -perspektiven der ehemaligen niedersächsischen Grenzregionen. In: Niedersächisches Institut für Wirtschaftsforschung (ed.). Entwicklungsprobleme und -perspektiven der ehemaligen niedersächsischen Grenzregionen. Hannover, 1-28.

Kruesemann, M. 2001. Entwicklunsgprobleme ausgewählter niedersächsischer Städte im ehemaligen Zonenrandgebiet. In: Niedersächisches Institut für Wirtschaftsforschung (ed.). Entwicklungsprobleme und -perspektiven der ehemaligen niedersächsischen Grenzregionen. Hannover, 75-92.

Moulton, B. R. 1990. An illustration of a pitfall in estimating the effects of aggregate variables on micro units. Review of Economics and Statistics 72, 334-338.

Sinn, H. W. and G. Sinn. 1992. Jumpstart. Cambridge, Mass.

Statistisches Bundesamt. 1999. Fachserie 1, R1 Gebiet und Bevölkerung. Stuttgart.

Zimmermann, K. F. 1995. Tackling the European migration problem. Journal of Economic Perspectives 9 (1995), 45-62. 


\section{CESifo Working Paper Series}

(for full list see www.cesifo.de)

1113 Volker Nitsch, Have a Break, Have a ... National Currency: When Do Monetary Unions Fall Apart?, January 2004

1114 Panu Poutvaara, Educating Europe, January 2004

1115 Torsten Persson, Gerard Roland, and Guido Tabellini, How Do Electoral Rules Shape Party Structures, Government Coalitions, and Economic Policies? January 2004

1116 Florian Baumann, Volker Meier, and Martin Werding, Transferable Ageing Provisions in Individual Health Insurance Contracts, January 2004

1117 Gianmarco I.P. Ottaviano and Giovanni Peri, The Economic Value of Cultural Diversity: Evidence from US Cities, January 2004

1118 Thorvaldur Gylfason, Monetary and Fiscal Management, Finance, and Growth, January 2004

1119 Hans Degryse and Steven Ongena, The Impact of Competition on Bank Orientation and Specialization, January 2004

1120 Piotr Wdowinski, Determinants of Country Beta Risk in Poland, January 2004

1121 Margarita Katsimi and Thomas Moutos, Inequality and Redistribution via the Public Provision of Private Goods, January 2004

1122 Martin Peitz and Patrick Waelbroeck, The Effect of Internet Piracy on CD Sales: CrossSection Evidence, January 2004

1123 Ansgar Belke and Friedrich Schneider, Privatization in Austria: Some Theoretical Reasons and First Results About the Privatization Proceeds, January 2004

1124 Chang Woon Nam and Doina Maria Radulescu, Does Debt Maturity Matter for Investment Decisions?, February 2004

1125 Tomer Blumkin and Efraim Sadka, Minimum Wage with Optimal Income Taxation, February 2004

1126 David Parker, The UK's Privatisation Experiment: The Passage of Time Permits a Sober Assessment, February 2004

1127 Henrik Christoffersen and Martin Paldam, Privatization in Denmark, 1980-2002, February 2004 
1128 Gregory S. Amacher, Erkki Koskela and Markku Ollikainen, Deforestation, Production Intensity and Land Use under Insecure Property Rights, February 2004

1129 Yin-Wong Cheung, Javier Gardeazabal, and Jesús Vázquez, Exchange Rate Dynamics: Where is the Saddle Path?, February 2004

1130 Alberto Alesina and Guido Tabellini, Bureaucrats or Politicians?, February 2004

1131 Gregory S. Amacher, Erkki Koskela, and Markku Ollikainen, Socially Optimal Royalty Design and Illegal Logging under Alternative Penalty Schemes, February 2004

1132 David M. Newbery, Privatising Network Industries, February 2004

1133 Charles Yuji Horioka, The Stagnation of Household Consumption in Japan, February 2004

1134 Eiji Fujii, Exchange Rate Pass-Through in the Deflationary Japan: How Effective is the Yen's Depreciation for Fighting Deflation?, February 2004

1135 Mark M. Spiegel and Nobuyoshi Yamori, Determinants of Voluntary Bank Disclosure: Evidence from Japanese Shinkin Banks, Febrary 2004

1136 Robert Dekle and Kenneth Kletzer, Deposit Insurance, Regulatory Forbearance and Economic Growth: Implications for the Japanese Banking Crisis, February 2004

1137 Takatoshi Ito and Kimie Harada, Bank Fragility in Japan, 1995-2003, February 2004

1138 Kunio Okina and Shigenori Shiratsuka, Policy Duration Effect under Zero Interest Rates: An Application of Wavelet Analysis, February 2004

1139 Francine D. Blau and Lawrence M. Kahn, Do Cognitive Test Scores Explain Higher U.S. Wage Inequality?, February 2004

1140 Michael Rauscher, Economic Growth and Tax-Competing Leviathans, February 2004

1141 Ernst Fehr and Jean-Robert Tyran, Money Illusion and Coordination Failure, February 2004

1142 Ingo Vogelsang, Network Utilities in the U.S. - Sector Reforms without Privatization, March 2004

1143 Marc-Andreas Muendler, Estimating Production Functions When Productivity Change is Endogenous, March 2004

1144 Sascha O. Becker, Samuel Bentolila, Ana Fernandes, and Andrea Ichino, Job Insecurity and Children's Emancipation, March 2004

1145 Pascalis Raimondos-Møller and Alan D. Woodland, Non-Preferential Trading Clubs, March 2004 
1146 Robert Fenge and Matthias Wrede, EU Regional Policy: Vertical Fiscal Externalities and Matching Grants, March 2004

1147 Chi-Yung Ng and John Whalley, Geographical Extension of Free Trade Zones as Trade Liberalization: A Numerical Simulation Approach, March 2004

1148 Marc-Andreas Muendler, Trade, Technology, and Productivity: A Study of Brazilian Manufacturers, 1986-1998, March 2004

1149 Eugene Beaulieu, Vivek H. Dehejia, and Hazrat-Omar Zakhilwal, International Trade, Labour Turnover, and the Wage Premium: Testing the Bhagwati-Dehejia Hypothesis for Canada, March 2004

1150 Giorgio Brunello and Francesca Gambarotto, Agglomeration Effects on EmployerProvided Training: Evidence from the UK, March 2004

1151 S. Brock Blomberg, Gregory D. Hess, and Athanasios Orphanides, The Macroeconomic Consequences of Terrorism, March 2004

1152 Bodo Sturm and Joachim Weimann, Unilateral Emissions Abatement: An Experiment, March 2004

1153 Wolfgang Ochel, Welfare-to-Work Experiences with Specific Work-First Programmes in Selected Countries, March 2004

1154 Jan K. Brueckner and Eric Pels, European Airline Mergers, Alliance Consolidation, and Consumer Welfare, March 2004

1155 Aaron Tornell, Frank Westermann, and Lorenza Martínez, NAFTA and Mexico's Economic Performance, March 2004

1156 George Economides, Sarantis Kalyvitis, and Apostolis Philippopoulos, Do Foreign Aid Transfers Distort Incentives and Hurt Growth? Theory and Evidence from 75 Aidrecipient Countries, March 2004

1157 Robert Fenge and Volker Meier, Are Family Allowances and Fertility-related pensions Siamese Twins?, March 2004

1158 Bruno S. Frey, Simon Luechinger, and Alois Stutzer, Valuing Public Goods: The Life Satisfation Approach, March 2004

1159 Jerome L. Stein and Guay C. Lim, Asian Crises: Theory, Evidence, Warning-Signals, March 2004

1160 Romain Ranciere, Aaron Tornell, and Frank Westermann, Crises and Growth: A ReEvaluation, March 2004

1161 Assaf Razin and Efraim Sadka, Transparency, Specialization and FDI, March 2004

1162 Ludger Woessmann, How Equal Are Educational Opportunities? Family Background and Student Achievement in Europe and the United States, March 2004 
1163 B.M.S. van Praag and Barbara E. Baarsma, Using Happiness Surveys to Value Intangibles: The Case of Airport Noise, March 2004

1164 Aaron Tornell, Frank Westermann, and Lorenza Martínez, The Positive Link Between Financial Liberalization, Growth, and Crises, March 2004

1165 Helge Berger and Carsten Hefeker, One Country, One Vote? Labor Market Structure and Voting Rights in the ECB, March 2004

1166 Clemens Fuest and Martin Kolmar, A Theory of User-Fee Competition, March 2004

1167 Friedrich Schneider and Robert Klinglmair, Shadow Economies around the World: What Do We Know?, April 2004

1168 Horst Raff and Nicolas Schmitt, Exclusive Dealing and Common Agency in International Markets, April 2004

1169 M. Hashem Pesaran and Allan Timmermann, Real Time Econometrics, April 2004

1170 Sean D. Barrett, Privatisation in Ireland, April 2004

1171 V. Anton Muscatelli, Patrizio Tirelli and Carmine Trecroci, Can Fiscal Policy Help Macroeconomic Stabilisation? Evidence from a New Keynesian Model with Liquidity Constraints, April 2004

1172 Bernd Huber and Marco Runkel, Tax Competition, Excludable Public Goods and User Charges, April 2004

1173 John McMillan and Pablo Zoido, How to Subvert Democracy: Montesinos in Peru, April 2004

1174 Theo Eicher and Jong Woo Kang, Trade, Foreign Direct Investment or Acquisition: Optimal Entry Modes for Multinationals, April 2004

1175 Chang Woon Nam and Doina Maria Radulescu, Types of Tax Concessions for Attracting Foreign Direct Investment in Free Economic Zones, April 2004

1176 M. Hashem Pesaran and Andreas Pick, Econometric Issues in the Analysis of Contagion, April 2004

1177 Steinar Holden and Fredrik Wulfsberg, Downward Nominal Wage Rigidity in Europe, April 2004

1178 Stefan Lachenmaier and Ludger Woessmann, Does Innovation Cause Exports? Evidence from Exogenous Innovation Impulses and Obstacles, April 2004

1179 Thiess Buettner and Johannes Rincke, Labor Market Effects of Economic Integration The Impact of Re-Unification in German Border Regions, April 2004 